\title{
Prevalence of anaemia in pregnancy at antenatal care booking in a teaching hospital in southern Nigeria
}

\author{
Esther Ijeoma Nonye-Enyidah*, Basil Omieibi A. Altraide, Awopola I. Jumbo
}

Department of Obstetrics and Gynaecology, Rivers State University Teaching Hospital (RSUTH), Port Harcourt, Rivers State, Nigeria

Received: 20 July 2021

Accepted: 10 August 2021

\section{*Correspondence:}

Dr. Esther Ijeoma Nonye-Enyidah,

E-mail: hernsi@yahoo.com

Copyright: ( ) the author(s), publisher and licensee Medip Academy. This is an open-access article distributed under the terms of the Creative Commons Attribution Non-Commercial License, which permits unrestricted non-commercial use, distribution, and reproduction in any medium, provided the original work is properly cited.

\begin{abstract}
Background: Anaemia in pregnancy is the commonest haematological condition seen in pregnant women in most developing countries. It is a global public health problem causing maternal and fetal morbidity and mortality. Objective was to determine the prevalence of anaemia and associated socio-demographic factors among pregnant women at booking at Rivers State University Teaching Hospital (RSUTH).

Methods: A retrospective study conducted from $1^{\text {st }}$ January, 2015 to $31^{\text {st }}$ December, 2020 at the antenatal clinic (ANC) of RSUTH. The laboratory records of 9990 pregnant women who booked for antenatal care were retrieved and reviewed. This included the socio-demographic characteristics and routine investigations. Data was extracted, coded and analyzed using the IBM statistical package for social sciences (SPSS) version 23.0 (Armonk, NY). P value $<0.05$ was considered statistically significant.

Results: Total number of women who booked for antenatal care was 9990 women. Of this, 8635 women were anaemic giving a prevalence rate of $86.4 \%$. Mild anaemia was seen in $7061(70.68 \%) ; 1546(15.48 \%)$ had moderate anaemia and $28(0.28 \%)$ had severe anaemia. Of $8635(86.4 \%)$ women who were anaemic, $1647(19.07 \%), 5036(58.32 \%)$ and $1952(22.61 \%)$ were seen in the first, second and third trimesters respectively. Mean and modal packed cell volume (PCV) were $29 \pm 3.1 \%$ and $29 \%$ respectively. The range of PCV was $18-42 \%$. Mean age was $31 \pm 4.7$ years and age range was 15-48 years. Modal parity was zero. Nulliparous and multiparous women accounted for $3586(35.9 \%)$ and 3751 $(37.5 \%)$ of the women respectively. There was a significant correlation between anaemia and age, parity, level of education, occupation and genotype at booking.

Conclusions: The prevalence of anaemia was unacceptably high. There is need for education on anaemia at the antenatal clinics and close monitoring of the interventional measures put in place to prevent anaemia in pregnancy, in order to improve the pregnancy outcome.
\end{abstract}

Keywords: Anaemia, PCV, Pregnancy, Antenatal care, Booking, RSUTH

\section{INTRODUCTION}

Anaemia in pregnancy is low blood haemoglobin concentration below $11 \mathrm{~g} / \mathrm{dl}$ or haematocrit level less than $33 \%$. It is a global health problem causing maternal and fetal morbidities and mortalities especially in developing countries. ${ }^{1-6}$ In $2011,38 \%$ of pregnant women aged 15-49 years were anaemic worldwide and the prevalence is highest in south Asia, Central and West Africa. ${ }^{1}$ This is as a result of poor diet and intake of vitamins, iron and folic acid during pregnancy. ${ }^{1-6}$ Other causes are haemorrhages, infections, worm infestation and haemoglobinopathies. Anaemia is the commonest complication seen in pregnancy affecting half of pregnant women worldwide. ${ }^{7-}$ 
9 This results from normal physiological changes that occur in pregnancy. The commonest type of anaemia is iron deficiency accounting for $50 \%$ of anaemia in women worldwide. ${ }^{1,3,10}$ Predisposing factors of anaemia in pregnancy are young age, grandmultiparity, low socioeconomic status, illiteracy, ignorance and short interpregnancy interval. ${ }^{4}$ Depending on the type and severity of anaemia, the pregnancy may end up in miscarriages, prematurity, intrauterine growth restriction (IUGR), intrauterine fetal death, stillbirth, low birth weight and perinatal mortality. ${ }^{1-6,11}$

World Health Organization (WHO) recommends daily iron and folic acid supplements for pregnant women and they are expected to check their haemoglobin concentration or packed cell volume every trimester if everything is normal. ${ }^{3}$

Correction of anaemia in pregnancy can either be with haematinics or blood transfusion. Information on the prevalence of anaemia and its risk factors in the hospital would go a long way to create awareness of this clinical condition. This will also reduce the adverse effects to the mother and baby. Hence this study aims at determining the prevalence of anaemia among pregnant mothers at antenatal booking at the RSUTH. The result will give an insight into the burden of anaemia in pregnancy in our environment.

\section{METHODS}

This is a retrospective study involving pregnant women, who booked for antenatal care at RSUTH from $1^{\text {st }}$ January 2015 to $31^{\text {st }}$ December, 2020. The hospital is a tertiary institution located in the southern part of Nigeria and serves as a major referral centre for all the primary and secondary centres and privately owned hospitals in and around the State. Rivers State has a population of more than 5 million. The antenatal clinic is run by obstetrics and gynaecology department of RSUTH. The average daily attendance to the antenatal clinic (ANC) is 70 women. The main religion in southern Nigeria is Christianity.

The data was obtained from laboratory registers where records of investigations done at booking in ANC were kept within the study period. Data obtained were sociodemographic characteristics and packed cell volume (PCV)/haemoglobin concentration (Hb conc) of all the women that registered for antenatal care. Blood ( $5 \mathrm{ml})$ was collected from each patient into a tube containing an anticoagulant, ethylenediaminetetraacetic acid (EDTA). A full blood count was performed on each sample. The data was analyzed using the IBM statistical package for social sciences (SPSS) version 23.0 (Armonk, NY). A pregnant woman was considered anaemic if $\mathrm{Hb}$ was $<11 \mathrm{~g} / \mathrm{dl}$ or PCV was $<33 \% .^{12}$ Mild anaemia was 9-10.9 g/dl, moderate anaemia was 7.0-8.9 g/dl and severe anaemia was $<7 \mathrm{~g} / \mathrm{dl}$. Comparative analysis was done with Chi square test and $\mathrm{p}$ value $<0.05$ was considered statistically significant.

\section{RESULTS}

There were 9990 women who registered for antenatal care during the study period. There were 1925 (19.3\%), 5822 $(58.3 \%)$ and $2243(22.4 \%)$ women in the first, second and third trimesters respectively. The yearly distribution of the women is shown in Figure 1. A total of 2030 (20.3\%), 2323 (23.3\%), 1369 (13.7\%), 1879 (18.8\%), 1761 (17.6\%) and $628(6.3 \%)$ women booked for antenatal care in 2015 , 2016, 2017, 2018, 2019 and 2020 respectively. This is shown in Figure 2.

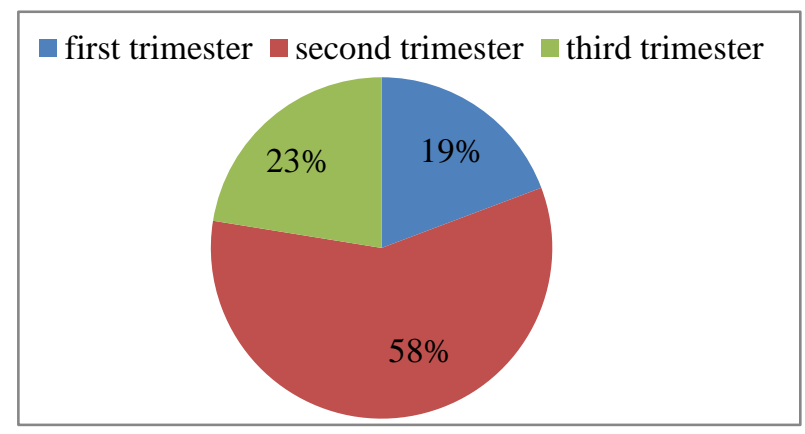

Figure 1: Number of antenatal women by trimester.

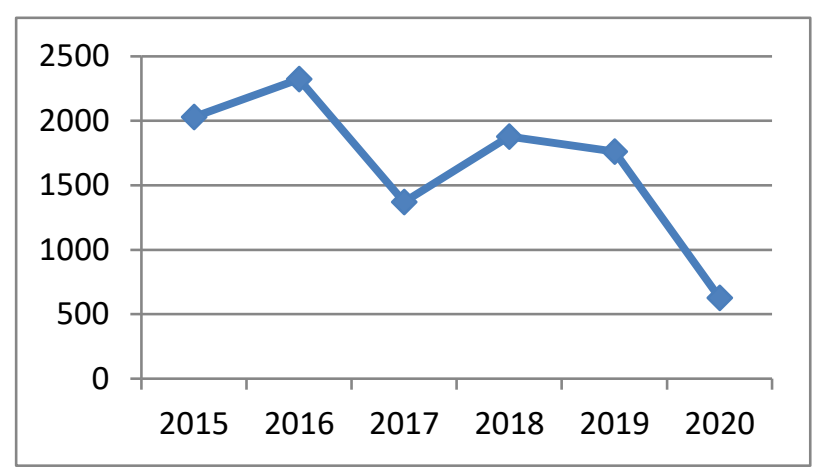

Figure 2: Yearly distribution of antenatal women.

A total of $9975(99.2 \%)$ women had formal education while $15(0.2 \%)$ had no formal education. Fifty eight $(0.6 \%)$ women had primary education while $2871(28.7 \%)$ and $7046(70.5 \%)$ had secondary and tertiary levels of education respectively. Two hundred and thirty seven $(2.4 \%)$ women were single while 9753 (97.6\%) were married. Mean age $\pm S$.D was $31.4 \pm 4.7$ years, age range was $15-48$ years and most women, $6234(62.4 \%)$ were in age group 30-39 years. Modal parity was para 0, parity range was $0-8$ and most women, 3751 (37.5\%) were multipara. Primigravida were $3586(35.9 \%)$ and grandmultigravida were 234 (2.3\%). Mean gestational age (GA) was 20.5 \pm 7.5 weeks and most $5822(58.3 \%)$ were in the second trimester (14-26 weeks). Most of the women, 3479 (34.8\%) were civil servants. The socio-demographic characteristics of the women by trimesters are shown in Table 1 .

A total of 8635 women had PCV less than $33 \%$ giving a prevalence rate of anaemia of $86.4 \%$. This is shown in Figure 3. Of this 8635 anaemic women, mild anaemia was 
found in $7061(70.68 \%)$, moderate anaemia was found in $1546(15.48 \%)$ and severe anaemia was seen in $28(0.28 \%)$ women. This is shown in Figure 4. A total of 1647 $(19.07 \%), 5036(58.32 \%)$ and $1952(22.61 \%)$ women were anaemic in the first, second and third trimesters respectively. This is shown in Table 2. Mean PCV during the study period was $29.3 \pm 3.2 \%$. The range of PCV was $18-42 \%$. Most women, $6219(62.3 \%)$ had PCV of $25-29 \%$.

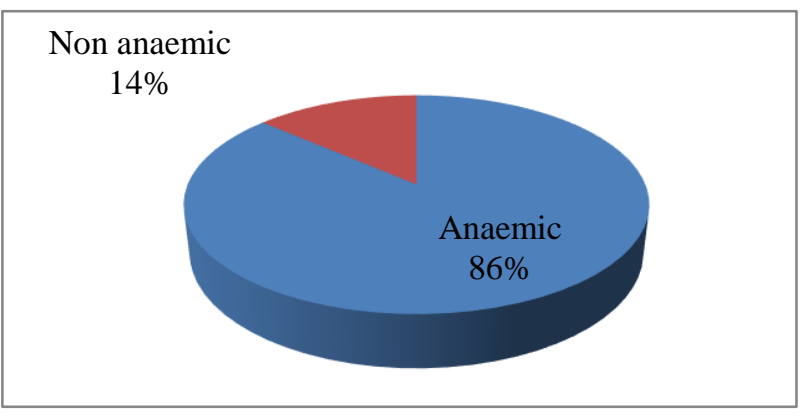

Figure 3: Prevalence of anaemia.

Table 3 shows comparison of anaemia with the sociodemographic factors in all the trimesters. Anaemia was most prevalent in the 30-39 years age group (62.6\%), followed by 20-29 years group (32.2) and $\geq 40$ years group (4.4\%). This was statistically significant. Most anaemia, $5036(58.3 \%)$ occurred in the second trimester, followed by third $1952(22 \%)$ and first $1647(19.1 \%)$ trimesters. The difference was not significant. Anaemia occurred most in women with tertiary level of education, 6055 (70.1\%). Anaemia was more prevalent in multigravida, 3433 $(39.8 \%)$ and primigravida, $3150(36.5 \%)$ compared to grandmultigravida, $208(2.4 \%)$ and the difference was statistically significant. More civil servants 2980 (34.5\%) and traders $2899(33.6 \%)$ had anaemia than the rest of women with other occupation and the difference was statistically significant. Table 4 shows the prevalence of anaemia according to genotype and HIV status of the women. All women with SS, AC and SC genotype were anaemic. Also anaemia was more prevalent among those with AA, $6619(76.65 \%)$ than those with AS genotype, 1971 (22.83\%). The difference was also significant. Of those that had anaemia, $8118(94.0 \%)$ were HIV negative while $517(6.0 \%)$ were HIV positive. The difference was not significant. Therefore there was a statistically significant relationship between anaemia and age, parity, education, occupation and genotype.

Table 1: Socio-demographic characteristics of women in first, second and third trimesters.

\begin{tabular}{|c|c|c|c|}
\hline Parameter & $\begin{array}{l}\text { First trimester } \\
\mathrm{N}=1925(\%)\end{array}$ & $\begin{array}{l}2^{\text {nd }} \text { trimester } \\
\mathrm{N}=\mathbf{5 8 2 2}(\%)\end{array}$ & $\begin{array}{l}3^{\text {rd }} \text { trimester } \\
\mathrm{N}=2243(\%)\end{array}$ \\
\hline \multicolumn{4}{|l|}{ Yearly breakdown } \\
\hline 2015 & $350(18.2)$ & $1179(20.3)$ & $501(22.3)$ \\
\hline 2016 & $401(20.8)$ & $1317(22.6)$ & $605(27.0)$ \\
\hline 2017 & $224(11.6)$ & $847(14.6)$ & $298(13.3)$ \\
\hline 2018 & $369(19.2)$ & $1113(19.1)$ & $397(17.7)$ \\
\hline 2019 & $441(22.9)$ & $998(17.1)$ & $322(14.4)$ \\
\hline 2020 & $140(7.3)$ & $368(6.3)$ & $120(5.3)$ \\
\hline Gestational age & $\leq 13$ & $14-26$ & $>26$ \\
\hline Mean & 10.45 & 19.7 & 31.26 \\
\hline Median & 11 & 20.0 & 31 \\
\hline Mode & 11 & 21 & 29 \\
\hline Range & 7 & 12 & 13 \\
\hline Maximum & 13 & 26 & 40 \\
\hline Minimum & 6 & 14 & 27 \\
\hline Standard deviation & 2.23 & 3.58 & 3.03 \\
\hline \multicolumn{4}{|l|}{ Educational status } \\
\hline No formal education & $0(0)$ & $12(0.2)$ & $3(0.1)$ \\
\hline Primary & $10(0.5)$ & $31(0.5)$ & $17(0.8)$ \\
\hline secondary & $472(24.5)$ & $1718(29.5)$ & $681(30.4)$ \\
\hline Tertiary & $1443(75)$ & $4061(69.8)$ & $1542(68.7)$ \\
\hline \multicolumn{4}{|l|}{ Occupation } \\
\hline Civil servants & $699(36.3)$ & $2137(36.7)$ & $643(28.7)$ \\
\hline Hair stylist & $54(2.8)$ & $123(2.1)$ & $43(1.9)$ \\
\hline Housewife & $291(15.1)$ & $1012(17.3)$ & $502(22.4)$ \\
\hline Lawyer & $2(0.1)$ & $9(0.2)$ & $4(0.2)$ \\
\hline Make-up artist & $5(0.3)$ & $9(0.2)$ & $16(0.7)$ \\
\hline Medical doctor & $0(0)$ & $3(0.1)$ & $3(0.1)$ \\
\hline Seamstress & $54(2.8)$ & $104(1.8)$ & $68(3.0)$ \\
\hline Students & $142(7.4)$ & $397(6.8)$ & $151(6.8)$ \\
\hline
\end{tabular}




\begin{tabular}{|c|c|c|c|}
\hline Parameter & $\begin{array}{l}\text { First trimester } \\
\mathrm{N}=1925(\%)\end{array}$ & $\begin{array}{l}2^{\text {nd }} \text { trimester } \\
\mathrm{N}=5822(\%)\end{array}$ & $\begin{array}{l}\mathbf{3}^{\text {rd }} \text { trimester } \\
\mathbf{N}=\mathbf{2 2 4 3}(\%)\end{array}$ \\
\hline Teacher & $38(2)$ & $139(2.4)$ & $37(1.6)$ \\
\hline Trader & $640(33.2)$ & $1889(32.4)$ & 776 (34.6) \\
\hline \multicolumn{4}{|l|}{ Marital status } \\
\hline Married & 1866 (96.9) & 5701 (97.9) & $2186(97.5)$ \\
\hline Single & $59(3.1)$ & $121(2.1)$ & $57(2.5)$ \\
\hline \multicolumn{4}{|l|}{ Age } \\
\hline Mean & 31.09 & 31.59 & 31.36 \\
\hline Median & 31 & 32.00 & 31 \\
\hline Mode & 30 & 30 & 30 \\
\hline Range & 32 & 33 & 30 \\
\hline Maximum & 48 & 48 & 46 \\
\hline Minimum & 16 & 15 & 16 \\
\hline Standard deviation & 4.574 & 4.68 & 4.92 \\
\hline \multicolumn{4}{|l|}{ Age groups } \\
\hline$\leq 19$ & $9(0.5)$ & $49(0.8)$ & $24(1.1)$ \\
\hline $20-29$ & $701(36.4)$ & $1785(30.7)$ & 761(33.9) \\
\hline $30-39$ & $1149(59.7)$ & $3725(64.0)$ & $1360(60.6)$ \\
\hline$\geq 40$ & $66(3.4)$ & $263(4.5)$ & $98(4.4)$ \\
\hline \multicolumn{4}{|l|}{ Parity } \\
\hline Mean & 1.06 & 1.39 & 1.44 \\
\hline Median & 1.00 & 1.00 & 1 \\
\hline Mode & 0 & 0 & 0 \\
\hline Range & 8 & 8 & 8 \\
\hline Maximum & 8 & 8 & 8 \\
\hline Minimum & 0 & 0 & 0 \\
\hline Standard deviation & 1.285 & 1.37 & 1.38 \\
\hline \multicolumn{4}{|l|}{ Parity groups } \\
\hline 0 & 909 (47.2) & $1989(34.2)$ & $688(30.7)$ \\
\hline 1 & $396(20.6)$ & $1426(24.5)$ & $597(26.6)$ \\
\hline $2-4$ & $585(30.4)$ & 2267 (38.9) & $899(40.1)$ \\
\hline$\geq 5$ & $35(1.8)$ & $140(2.4)$ & $59(2.6)$ \\
\hline
\end{tabular}

Table 2: Prevalence of anaemia by trimesters.

\begin{tabular}{|lll|}
\hline Trimester & Frequency & Percent (\%) \\
\hline First & 1647 & 19.07 \\
\hline Second & 5036 & 58.32 \\
\hline Third & 1952 & 22.61 \\
\hline
\end{tabular}

Table 3: Anaemia and socio-demographic characteristics in all trimester.

\begin{tabular}{|c|c|c|c|c|}
\hline Parameter & $H b<11(\%)$ & $\mathrm{Hb} \geq 11(\%)$ & $\mathbf{X}^{2}(\%)$ & P value \\
\hline \multicolumn{5}{|l|}{ Age groups } \\
\hline$\leq 19$ & $65(0.8)$ & $17(1.3)$ & 9.71 & 0.021 \\
\hline $20-29$ & $2778(32.2)$ & $469(34.6)$ & & \\
\hline $30-39$ & $5410(62.6)$ & $824(60.8)$ & & \\
\hline$\geq 40$ & $382(4.4)$ & $45(3.3)$ & & \\
\hline \multicolumn{5}{|c|}{ Parity groups } \\
\hline 0 & $3150(36.5)$ & $436(32.2)$ & 304.94 & 0.000 \\
\hline 1 & $1844(21.3)$ & $575(42.4)$ & & \\
\hline $2-4$ & $3433(39.8)$ & $318(23.5)$ & & \\
\hline$\geq 5$ & $208(2.4)$ & $26(1.9)$ & & \\
\hline \multicolumn{5}{|c|}{ GA (trimester) } \\
\hline$\leq 13$ & $1647(19.1)$ & $278(20.5)$ & 1.951 & 0.377 \\
\hline
\end{tabular}




\begin{tabular}{|lllll|}
\hline Parameter & Hb $<11(\%)$ & Hb $\geq 11(\%)$ & $\mathbf{X}^{2}(\%)$ & P value \\
\hline $14-26$ & $5036(58.3)$ & $786(58.0)$ & & \\
\hline$>26$ & $1952(22.6)$ & $291(21.5)$ & & \\
\hline Marital status & & & 2.446 & \\
\hline Married & $8422(97.5)$ & $1331(98.2)$ & & 0.049 \\
\hline Single & $213(2.5)$ & $24(1.8)$ & (Fisher exact test 8.102$)$ & 0.038 \\
\hline Education status & & & & \\
\hline No formal edu & $11(0.1)$ & $4(0.3)$ & & \\
\hline Primary & $50(0.6)$ & $8(0.6)$ & & \\
\hline Secondary & $2519(29.2)$ & $352(26.0)$ & \\
\hline Tertiary & $6055(70.1)$ & $991(73.1)$ & \\
\hline Occupation & & & & \\
\hline Civil servants & $2980(34.5)$ & $499(36.8)$ & \\
\hline Hair stylist & $197(2.3)$ & $23(1.7)$ & & \\
\hline Housewife & $1538(17.8)$ & $267(19.7)$ & \\
\hline Lawyer & $11(0.1)$ & $4(0.3)$ & & \\
\hline Makeup artist & $29(0.3)$ & $1(0.1)$ & & \\
\hline Medical doctor & $6(0.1)$ & $0(0)$ & & \\
\hline Seamstress & $200(2.3)$ & $26(1.9)$ & & \\
\hline Students & $602(7)$ & $88(6.5)$ & & \\
\hline Teacher & $173(2)$ & $41(3)$ & & \\
\hline Trader & $2899(33.6)$ & $406(30)$ & & \\
\hline
\end{tabular}

Table 4: Comparison of anaemia with genotype and HIV status.

\begin{tabular}{|lllll|}
\hline Paarameters & $\mathrm{Hb}<\mathbf{1 1}(\%)$ & $\mathrm{Hb} \geq \mathbf{1 1}(\%)$ & $\mathbf{X}^{2}(\%)$ & P value \\
\hline Genotype & & & 57.55 & 0.000 \\
\hline AA & $6619(76.65)$ & $1160(85.61)$ & (Fisher exact test 62.03) & \\
\hline AS & $1971(22.83)$ & $195(14.39)$ & & \\
\hline SS & $37(0.43)$ & $0(0.00)$ & & 0.458 \\
\hline AC & $3(0.03)$ & $0(0.00)$ & & \\
\hline SC & $5(0.06)$ & $0(0.00)$ & & \\
\hline HIV status & & & & \\
\hline Negative & $8118(94.0)$ & $1281(94.5)$ & & \\
\hline Positive & $517(6.0)$ & $74(5.5)$ & & \\
\hline
\end{tabular}

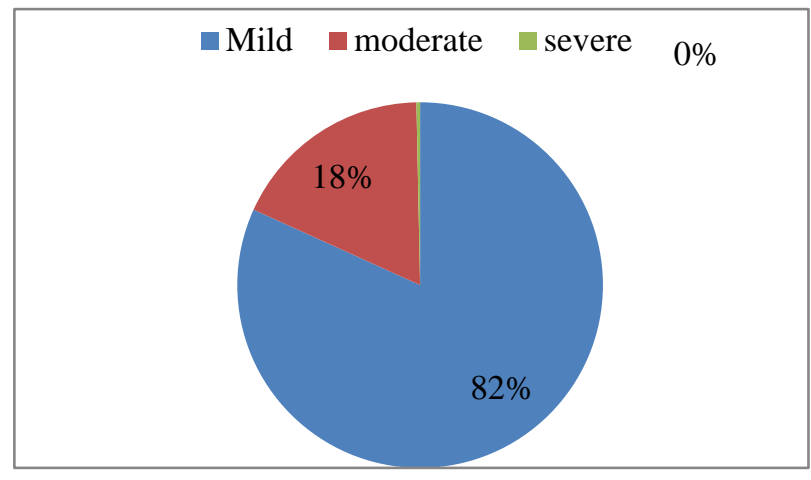

Figure 4: Grade of anaemia.

\section{DISCUSSION}

The prevalence of anaemia in this study is $86.4 \%$. This is far too high and unacceptable knowing the implications of this level of anaemia in our pregnant mothers. This figure is higher than $56.8 \%$ observed in Eastern Ethiopia and
Somali respectively, 51.9\% in Southern Ethiopia and 36\% in East Africa. ${ }^{2}$ In Northern and southern Ghana, the prevalence of anaemia among pregnant mothers was $70 \%$, $50.8 \%$ and $57.1 \%$ respectively. ${ }^{3,13,14}$ In Kiboga, Uganda and Derna, Libya the prevalence were $63.1 \%$ and $54.6 \%$ respectively. ${ }^{15,16}$ In south-south and eastern parts of Nigeria, prevalence rates of $69.6 \%$ and $58 \%$ were reported respectively. ${ }^{6,17}$ The differences in the prevalence of anaemia may be as a result of poor dietary intake, economic status, socio-cultural, religious, poor health seeking behaviour and preventive health practices. ${ }^{4,18}$ The pregnant women may not have had enough iron and folic acid from their diet or supplement use to support the pregnancies. There is an extra demand of iron during pregnancy for fetal growth and development and dietary sources alone is not enough to take care of this. A lot of pregnant women don't take their iron and folic acid supplements probably because of side effects of the elemental iron or not liking to take oral drugs. ${ }^{3}$ In a study done in 2009, anaemia prevalence increased with noncompliance with iron supplements as pregnancy 
progressed and the non-compliant pregnant women were 6 times more likely to be anaemic compared to those compliant. ${ }^{19}$ Also infections like malaria, urinary tract infection (UTI), worm infestation, haemoglobin genotype, human immunodeficiency virus (HIV) infection and increase blood loss in bleeding increase the risk of anaemia. ${ }^{3,20}$

The principle of anaemia prevention in our centre is to control malaria and administer haematinics supplementation. All the booked pregnant women are screened and treated for anaemia, they also receive daily routine haematinics in the form of iron and folic acid. Malaria prophylaxis is with intermittent preventive treatment (IPT) of asymptomatic women with sulphadoxime-pyrimethamine combination after quickening. Malaria is also diagnosed early and prompt treatment instituted. There is also health education on diet and other ways of preventing anaemia in pregnancy. Insecticide treated nets for the pregnant mothers are no longer available in the antenatal clinic. Our booked mothers are also not routinely dewormed. Over the six years of study, the antenatal booking number fluctuates between 628 in 2020 and 2323 women in 2016. The number dropped drastically in 2020 due to COVID-19 pandemic. Most women registered for antenatal care in the second trimester indicating that most of our women register late for antenatal care therefore worsening and increasing the prevalence of anaemia at booking in the hospital. The mean PCV of $29 \%$ throughout the three trimesters is anaemia by World Health Organization (WHO) standard. Majority of the women in this study had mild anaemia and only $0.25 \%$ had severe anaemia. This finding is similar to other findings unlike an earlier study in the same centre with majority of the women having moderate anaemia. ${ }^{4,6,21-23}$ Most women with mild anaemia can survive pregnancy and delivery without complications but those with moderate and severe anaemia are at risk of maternal and fetal morbidities and mortalities. ${ }^{6}$

The number of anaemic women increased with maternal age. This is similar to findings from other studies, ${ }^{4,24-26}$ Some studies reported anaemia to be more in primigravida because of the risk of severe malaria in this group of women. $^{27,28}$ The result of a meta-analysis showed that primigravidae were $61 \%$ less likely to develop anaemia during pregnancy compared to multiparae because of the effect of repeated pregnancy in depleting the iron store of a pregnant woman. ${ }^{2,29}$ A study done in Malaysia found a higher proportion of anaemia among grandmultigravida. ${ }^{30}$ However in this study, the number of multigravidae with anaemia is greater than the anaemic primigravidae. This is similar to other studies. ${ }^{31-33}$ Anaemia in this study was significantly associated with parity, age, educational status, occupation and genotype. This is similar to an earlier study although anaemia in the earlier study was also significantly associated with gestational age. ${ }^{6}$ More civil servants and traders had anaemia than the rest of the occupation and the difference was statistically significant.
Some studies showed that anaemia was associated with low socio-economic and low educational staus. ${ }^{6,31,34}$ In this study, surprisingly anaemia was more prevalent in women with high level of education possibly because this group of women make up the majority of the women in this study and they also registered late in the second trimester of pregnancy due to delay in health seeking behaviour seen in our women. Anaemia in this study, occurred least among women who booked for antenatal care in the first trimester and highest in the second trimester of pregnancy. This is finding is similar to other studies. ${ }^{4,6,18,24}$ This may be due to the fact that our women register late in the second and third trimesters when the dilutional effect of pregnancy and increased fetal demand are maximal. Also any anaemia that was not treated in the first trimester is likely to worsen in the second and third trimesters of pregnancy. ${ }^{4,6}$

As expected, all the sicklers in the study were anaemic. This was also the case in earlier study. ${ }^{6}$ Most $(77 \%)$ of the women who were anaemic had genotype AA and this was statistically significant. Also most women in the study were HIV negative and $94 \%$ of these women were anaemic compared to $6 \%$ of the women who were HIV positive. This finding is different from an earlier study in the department where anaemia was more prevalent in women who were HIV positive. ${ }^{6}$

\section{CONCLUSION}

The unacceptably high prevalence of anaemia from this study is an indeed a public health problem and needs urgent attention to prevent maternal and fetal morbidities and mortalities. Extra measures should be put in place to make sure that our women take their routine antenatal drugs; long lasting insecticide treated nets should be given to our antenatal mothers during booking. Majority of the booking were in the second trimester therefore our women should be encouraged and educated on the usefulness and benefits of registering early for antenatal care. Also education on anaemia causes and consequences, the usefulness of diet and dietary supplements in pregnancy should be emphasized to prevent anaemia in pregnancy.

\section{ACKNOWLEDGEMENTS}

Authors would like to express their gratitude to the staff of the haematology department for the assistance rendered for this study.

\section{Funding: No funding sources Conflict of interest: None declared \\ Ethical approval: The study was approved by the Institutional Ethics Committee}

\section{REFERENCES}

1. Stevens GA, Finucane MM, De-Regil LM, Paciorek CJ, Flaxman SR, Branca F, et al. Global, regional, and national trends in haemoglobin concentration and 
prevalence of total and severe anaemia in children and pregnant and non-pregnant women for 1995-2011: a systematic analysis of population representative data. Lancet Glob Health. 2013;1(1):16-25.

2. Kassa GM, Muche AA, Berhe AK, Fekadu GA. Prevalence and determinants of anaemia among pregnant women in Ethiopia; a systematic review and meta-analysis. BMC Haematology. 2017;17(17):1-9.

3. Wemakor A. Prevalence and determinants of anaemia in pregnant women receiving antenatal care at a tertiary referral hospital in Northern Ghana. BMC Pregnancy and Childbirth. 2019;19(495):1-11.

4. Olatunbosun O, Abasiattai AM, Bassey EA, James RS, Ibanga S, Morgan A. Prevalence of anaemia among pregnant women at booking in the university of Uyo Teaching Hospital, Uyo, Nigeria. BioMed Research Int. 2014;1-8.

5. Stephen G, Mgongo M, Hashim TH, Johnson K, Stray-Pedersen B, Msuya SE. Anaemia in pregnancy: Prevalence, risk factors and adverse perinatal outcomes in Northern Tanzania. Anaemia. 2018;1-9.

6. Okoh DA, Iyalla C, Omunakwe H, Iwo-Amah RS, Nwabuko C. A retrospective study of the prevalence of anaemia in pregnancy at booking in Niger Delta, Nigeria. J Obstet Gynaecol. 2016;36(5):594-7.

7. McClure EM, Goldenberg RL, Dent AE, Meshnick SRA. Systematic review of the impact of malaria prevention in pregnancy on low birth weight and maternal anemia. Int $\mathrm{J}$ Gynaecol Obstet. 2013;121(2):103-9.

8. Lee AI, Okam MM. Anemia in pregnancy. Hematol Oncol Clin North Am. 2011;25(2):241-59.

9. Karaoglu L, Pehlivan E, Egri M, Deprem C, Gunes G, Genc MF, et al. The prevalence of nutritional anemia in pregnancy in an east Anatolian province, Turkey. BMC Public Health. 2010;10:329.

10. Olubukola A, Odunayo A, Adesina O. Anemia in pregnancy at two levels of health care in Ibadan, south west Nigeria. Ann Afr Med. 2011;10(4):272-7.

11. Msuya SE, Hussein TH, Uriyo J, Sam NE, and StrayPedersen B, "Anaemia among pregnant women in northern Tanzania: prevalence, risk factors and effect on perinatal outcomes." Tanzania J Health Res. 2011;13(1):33-9.

12. WHO. Global nutrition targets 2025: anaemia policy brief (WHO/NMH/NHD/ 14.4). Geneva: World Health Organization. 2014.

13. Saaka M, Oladele J, Larbi A, Hoeschle-Zeledon I. Dietary diversity is not associated with haematological status of pregnant women resident in rural areas of northern Ghana. J Nutr Metab. 2017;1 10.

14. Glover-Amengor M, Owusu W, Akanmori B. Determinants of anaemia in pregnancy in Sekyere West District, Ghana. Ghana Med J. 2005;39(3):102.

15. Mbule MA, Byaruhanga YB, Kabahenda M, Lubowa A, Mbule M. Determinants of anaemia among pregnant women in rural Uganda. Rural Remote Health. 2013;13(2):2259.
16. Elzahaf RA, Omar M. Prevalence of anaemia among pregnant women in Derna city, Libya. Int $\mathbf{J}$ Community Med Public Health. 2016;3(7):1915-20.

17. Onoh R, Lawani O, Ezeonu P, Nkwo P, Onoh T, Ajah L. Predictors of anemia in pregnancy among pregnant women accessing antenatal care in a poor resource setting in south eastern Nigeria. Sahel Med J. 2015;18(4):182.

18. Bukar M, Audu BM, Sadauki HM, Elnafaty AU, Mairiga AG. Prevalence of iron deficiency and megaloblastic anaemia at booking in a secondary Health facility in North Eastern Nigeria. Nig J Med. 2009;50(2):33-7.

19. Habib F, Alabdin EH, Alenazy M, Nooh R. Compliance to iron supplementation during pregnancy. J Obstet Gynaecol. 2009;29(6):487-92.

20. Orish VN, Onyeabor OS, Boampong JN, Acquah S, Sanyaolu AO, Iriemenam NC. The effects of malaria and HIV co-infection on hemoglobin levels among pregnant women in Sekondi-Takoradi, Ghana. Int J Gynecol Obstet. 2013;120(3):236-9.

21. Ugwuja EI, Akubugwo EI, Ibiam UA, Onyechi O. Impact of maternal iron deficiency and anaemia on pregnancy and its outcomes in a Nigerian population. The Internet Journal of Nutrition and Wellness. 2010;10(1):1-11.

22. Aluka C, Amadi AN, Kamamu CI, and Feiyi Waboso PA, "Anaemia in pregnancy in Abia State University teaching hospital, Aba. Journal of Medical Investigation and Practice. 2001;2:58-61.

23. Adinma JIB, Ikechebelu JI, Onyejimbe UN, Amilo G, Adinma E. Influence of antenatal care on the haematocrit Value of pregnant Nigerian Igbo Women. Trop J Obstet Gynaecol. 2002;19(2):68-70.

24. Komolafe JO, Kuti O, Oni O, Egbewale BE. Sociodemographic characteristics of anaemic gravidae at booking: a preliminary study at Llesha, Western Nigeria. Niger J Med. 2005;14(2):151-4.

25. Geelhoed D, Agadzi F, Visser L. Severe anemia in pregnancy in rural Ghana: a case-control study of causes and management. Acta Obstetricia et Gynecologica Scandinavica. 2006;85(10):1165-71.

26. Hogue AKM, Kadar SB, Hogue E, Mugero C. Prevalence of anaemia in pregnancy at Greytown, South Africa. Trop Obstet Gynaecol. 2006;23(1):3-7.

27. Anorlu RI, Oluwole AA, Abudu OO. Sociodemographic factors in anaemia in pregnancy at booking in Lagos, Nigeria. J Obstet Gynaecol. 2006;26(8):773-6.

28. Bisen PI, Uko EK, Jeremiah ZA, Usanga EA, Prevalence and risk factors of anaemia among pregnant women in Nigeria. The Open Haematology Journal, 2008;2:14-9.

29. Dewey KG, Cohen RJ. Does birth spacing affect maternal or child nutritional status? A systematic literature review. Maternal \& child nutrition. 2007;3(3):151-73.

30. Nik Rosmawati N, Mohd Nazri S, Mohd II. The rate and risk factors for anemia among pregnant mothers 
in Jerteh Terengganu, Malaysia. J Community Med Health Educ. 2012;2(150):2161-71.

31. Melku M, Addis Z, Alem M, Enawgaw B. Prevalence and predictors of maternal anemia during pregnancy in Gondar, Northwest Ethiopia: an institutional based cross-sectional study. Anemia. 2014;9.

32. Gwarzo MY, Ugwu EA. The pattern of anaemia in Northern Nigerian pregnant women. J Med Medical Sci. 2013;4:319-23.

33. Ndukwu GU, Dienye PO. Prevalence and sociodemographic factors associated with anaemia in pregnancy in a primary health centre in Rivers State, Nigeria. African Journal of Primary Health Care and Family Medicine, 2012;4:1-7.
34. Lokare PO, Karanjekar VD, Gattani PI. Kulkami VD. A study of the prevalence of anaemia and sociodemographic factors associated with anaemia among pregnant women in Auran Gabad City, India. Annals of Nigerian Medicine. 2012;6:30-4.

Cite this article as: Nonye-Enyidah EI, Altraide BOA, Jumbo AI. Prevalence of anaemia in pregnancy at antenatal care booking in a teaching hospital in southern Nigeria. Int J Reprod Contracept Obstet Gynecol 2021;10:3287-94. 